\title{
An Efforts to Increase Efficiency Cost and Productivity Production at PT. XYZ
}

\author{
Sekar Kumudasari \\ Master of Management, Mercubuana University \\ Jakarta, Indonesia
}

\begin{abstract}
This thesis aim to examine regarding layout methods, efficiency, productivity and fishbone towards efficiency cost in an effort to increasing the product productivity on Development sample room department at PT XYZ in which to sort of current problem regarding extra costs which exceed the company's target every monthly and The company's desire to increasing the output result during period July 2018 until December 2018. This research has purpose to discover the influence of an increasing efficiency cost and increasing productivity through layout method, efficiency, productivity and fishbone towards efficiency cost and productivity on Development Sample Room at PT XYZ. The research results shows there has an increasing in efficiency cost around $27 \%$ which nominal amounted Rp.13.200 / monthly therefore there has decreed in actual cost with that amount aswell. The influence of layout that transform the distance from previously in $\mathbf{4 0 0 . 5} \mathrm{m}$ into $\mathbf{1 4 3}$ metres so it makes the production process faster and more efficient as for productivity, there has no increase in it because basically the target or order has been received to be completed that month.
\end{abstract}

Keywords:- Layout, Efficiency, Productivity and Fishbone.

\section{INTRODUCTION}

\section{A. Background of Problems}

One problem which often occured in world industry especially in manufacturing industry is layout and raw materials productions. This related to the use of proper technology, in accordance with and in line with work type and an understanding how to utilize humans as workers as much as possible with purposed in achieving the highest productivity, efficiency and effectiveness. Part of the harmonization to be called production layout such as the layout of placement of machines and raw materials that could support production activities from the transfer of raw materials to the production process used so the production activities run effectively and efficiently.

PT XYZ is a company which operated in manufactures shoes for Adidas brand. The shoe making of PT Panarub products has several stages of process that should be passed the criteria which namely: the process of taking raw material in warehouse, the process of cutting raw material, subcont process, sewing process, assembling process and last is final process which is packaging. Production layout arrangements at PT. XYZ are needed to be more effective so there would be no stumble in

\author{
Dana Santoso Saroso \\ Lecturer of Postgraduate, Mercubuana University \\ Jakarta, Indonesia
}

production process. A good layout specifically would be able to provide benefits in the production system such as increasing production output, reduce the waiting time (delay), reduce the moving material process (material handling) and saving the areas for the use of production, warehouses and services. From these benefits above, it is expected to be used in research at PT. XYZ, Development Sample Room department which in 2018 the costs expenses did not reach the following target.

\begin{tabular}{ccc}
\hline Month & Cost Target / Month & Actual/ Month Fee \\
\hline July & Rp $70,658,340$ & Rp 258,497,399 \\
August & Rp $70,658,340$ & Rp 642,907,705 \\
September & $\operatorname{Rp~} 70,658,340$ & Rp 258,497,399 \\
October & Rp $70,658,340$ & Rp 258,497,399 \\
November & Rp 70,658,340 & Rp 153,317,919 \\
December & Rp 70,658,340 & Rp 111,682,659 \\
\hline Total 2018 & Rp 423,950,000 & Rp 1,683,400,480 \\
\hline \multicolumn{2}{c}{ Table 1:- Actual-Target Costs Per Month, 2018 }
\end{tabular}
Source: PT XYZ (2019)

From this result stated that a deeper test is needed to solve the current problems which faced by PT XYZ for Development Sample Room department. The Analysis could be done through facility layout design by using the linkages diagram commonly used in plant layouts by considering the interrelationship between departments through the Activity Relationship Chart (ARC) method, the Productivity Method, the Efficiency Method and the Fishbone Method. Based on this research it is hoped that it could help the Development Sample room department PT $\mathrm{XYZ}$ can reach its goals in order to achieving the main targets. Based on the description above, the writer was interested in taking the title "An Efforts to Increase Efficiency Cost and Productivity Production at PT. XYZ".

\section{B. Research Purposes}

There are several purpose which to be want to reach in carrying out this research such as:

$>$ Knowing there has an increase in efficiency cost in Sample Room Development department at PT XYZ.

$>$ Knowing there has an increase in production productivity on Department of Development Sample Room at PT XYZ.

$>$ Knowing there has an factors which causing the output and costs do not approach or target missed on Department of Development Sample Room at PT XYZ. 


\section{THEORITICAL REVIEW}

\section{A. Layout}

Based on Haizer and Render (2011) Layout is a decision including the placement of machines in the best place (in production arrangements), offices and desks (in office settings) or service centers (in hospital or supermarket management). The Factory layout are includes planning and layout of machinery, equipment, material flow and people who work at each work station. If its arranged properly, work operations will become more effective and efficient (Wignjosoebroto, 2009).

Wignjosoebroto (2009:69) stated that the selection and placement over alternative layouts is a critical step in production facility planning process, because that the chosen layout will determine the physical relationship of an ongoing production activities. As for several types of facility layout based on production flow which namely 1) Layout based on Production Flow, 2) Layout based on Function or Types of Process, 3) Layout based on Fixed Location and 4) Layout based on Product Groups.

\section{B. Activity Relationship Chart}

According to Purnomo (2004) the Activity Relationship Chart whose developed by Muther is a simple technique in planning the layout of facilities. This method connects several activities in pairs so all activities will be known to their level of connections. Those connections could be expressed qualitatively even there has some parties who valued as quantitatively. In ARC there are several changes or those variables to replace quantitative figures. The variable is in form of symbolizing which defined the level of closeness between one department and another. In general, there has an related reasons which divided into three types which is related to production, related to employees and related to information flow. The symbols are used to indicate the interrelation levels between activities such as follows:

\begin{tabular}{|c|c|c|}
\hline Score & Colour & Closeness Relationship \\
\hline A & Red & Absolutely need to be brought near \\
\hline E & Yellow & Very important to be brought near \\
\hline I & Green & Important to be brought near \\
\hline O & Blue & Enough/ordinary \\
\hline U & White & Not important \\
\hline X & Brown & Undesirable to get close \\
\hline
\end{tabular}

Table 2:- Symbols in Activity Relationship Chart (ARC)

\section{Productivity}

Productivity based onTimpe (1984) is the ratio of valuable outputs and inputs, for example the efficiency and effectiveness of available resources, such as staffing, machinery, materials, capital, facilities, energy and time to achieve highly valued outputs. Gasperz (2000) illustrated that productivity views from two sides at once namely in terms of input and output, it could be stated that productivity is related to efficiency of the use an inputs in producing output (goods / services) or in other words productivity is combination between effectiveness and efficiency. For this reason productivity could be measured by sizing output which divided by input.

According to Prima (2015:140) productivity action which need to carried out by each company so it could get known how current condition of company is, whether the level of productivity is accordance with the standards set or not. Summanth (1984) was introduced earlier with formal concept to be called the productivity cycle and used in efforts to increase productivity continuously. The productivity theory was presented as a continuous process and involves of measurement, evaluation, planning, and productivity control aspectes.

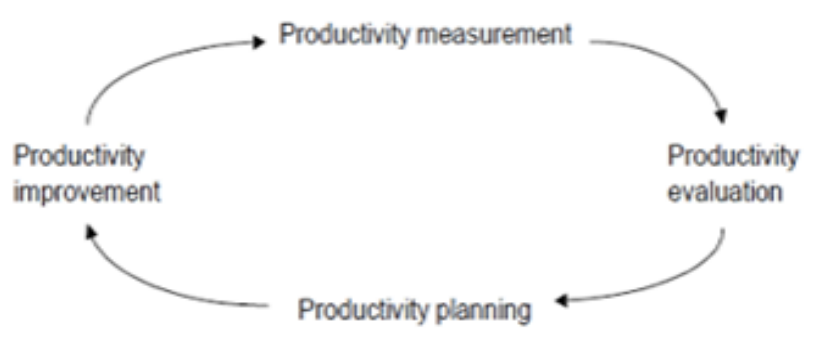

Fig 1:- Productivity cycle Source: Summanth (1984)

\section{Efficiency}

According to Mulyamah (1987: 3) the definition of efficiency is a measure in comparing plans for the use of inputs with realized uses or other words of actual use. Meanwhile according to S.P. Hasibuan (1984:233-4) efficiency is the best comparison between input and output (the result of profits with the sources used). Furthermore, according to Asfihan (2019) said that efficiency efforts would defined successful if they meet several requirements such as 1) Effective, 2) Economical, 3) Work performance which could be responsible for, 4) fairly work divided , 5) Rationality of authority and responsibility and 6) Practical work procedures.

\section{E. Production Cost}

According to Hansen and Mowen who'd been translated by Deny Arnos Kwary (2009:56) stated that production costs are costs whose associated with making goods and providing services. Meanwhile, according to Mulyadi (2009:14) production costs are service costs that incurred in raw materials process into outturn products which ready to sell. From those understanding, the authors conclude that the production costs are all costs incurred by the company during the processing of raw materials to finished as Goods and ready to sell.

\section{F. Fishbone Diagram}

Fishbone diagrams often used when we want to identify possible causes of problem especially when teams tend to fall into routine thinking (Tague, 2005). The benefits of this fishbone diagram could help us to discover the root causes of problems in user friendly, user friendly tool which loved by people in manufacturing industry 
where the process there is known to have a wide variety of variables that has potential to causing problems. Fishbone diagrams could identify various potential causes of an effect or problem and analyze the problem through brainstorming session. The problem will be solved into a number of related categories, including humans, materials, machines, procedures, policies and so on (Purba, 2008).

\section{G. Thinking Framework}

Based on discussion of theoretical studies and research phenomena, the writer could summarizes systematically the link between research phenomena as in these following framework:

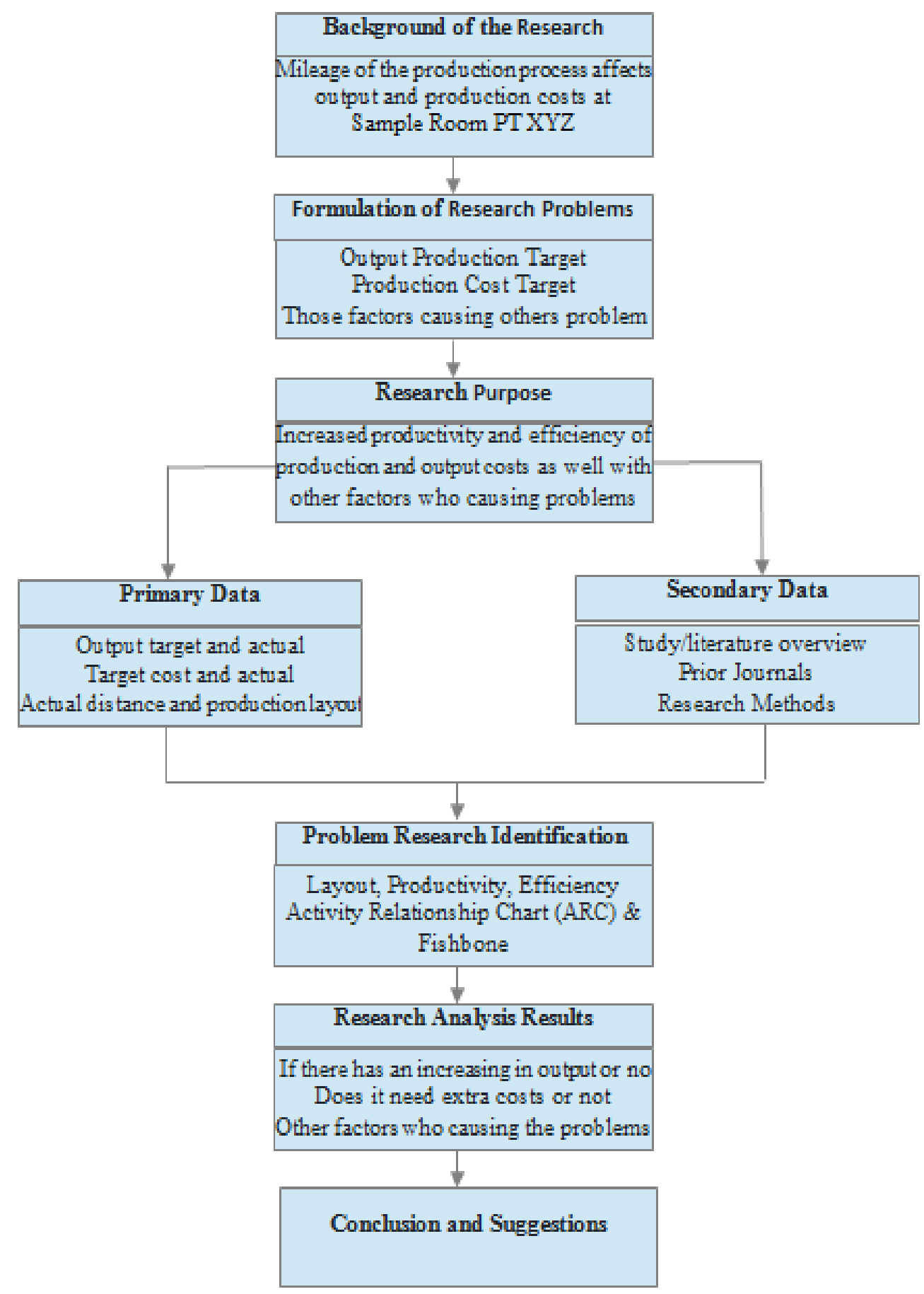

Fig 2:- Thinking Framework 


\section{METHODOLOGY}

The authors used quantitative and descriptive research methods on this research. Which consists the variables into layout, productivity, and efficiency. The population is the wide location between factory facilities, production costs and those amount of output produced by PT XYZ. The sample used the distance between the location of the factory facilities, target costs and actual costs of production, the number of targets and actual output of PT XYZ at Development Sample Room in July to December in 2018. Sampling earned from these months due to data based on the 6-month season of shoe making namely the Spring Summer (SS) and Fall Winter (FW) seasons.

Primary data in this research, the researchers observation during this research at PT XYZ. Secondary data used primary data that has been processed which obtained from the vast distance of the factory layout location, production cost reports and the number of PT XYZ's Development Sample Room outputs, as well as library studies. Data analysis methods were divided into five stages, namely 1) Analysis using the company's facility layout method, 2) Analysis using the productivity method, 3) Analysis using the production cost efficiency method, Analysis using the fishbone method, and 5) Comparison of the results of the analysis prior and after analysis done.

\section{RESULTS AND DISCUSSION}

\section{A. Layout Method}

The sample room department has several work stations such as warehouse, cutting, preparation and so on. Each station has a distance, process rotation and frequency that can be shown as follows.

\begin{tabular}{|c|c|c|c|c|c|c|}
\hline $\begin{array}{l}\text { Work } \\
\text { Station }\end{array}$ & From & To & $\begin{array}{l}\text { Distance } \\
\text { (Meter) }\end{array}$ & $\begin{array}{l}\text { Process Turnaround } \\
\text { (Minute) }\end{array}$ & $\begin{array}{c}\text { Transfer } \\
\text { Frequent / } \\
\text { Hour }\end{array}$ & $\begin{array}{c}\text { Transfer Time / } \\
\text { Day } \\
\text { (Minute) }\end{array}$ \\
\hline 1 & Warehouse & Cutting & 12,8 & 4,5 & 4 & 144,00 \\
\hline 3 & Subcont Upper & Preparation & 16,6 & 3,5 & 4 & 112,00 \\
\hline 4 & Preparation & Sewing & 27,6 & 5 & 4 & 160,00 \\
\hline 5 & Sewing & Upperbank & 30 & 5 & 4 & 160,00 \\
\hline 8 & Assembling & Inspection & 15,6 & 3,6 & 4 & 115,20 \\
\hline 9 & Inspection & Packing & 110 & 8,4 & 4 & 268,80 \\
\hline \multirow[t]{2}{*}{10} & Packing & Exsport & 116,8 & 9 & 4 & 288,00 \\
\hline & TOTAL & & 400,50 & & & 1673,60 \\
\hline
\end{tabular}

Table 3:- Calculation of Initial Layout Between Distance and Time of Transfer Per Day in Sample Room at PT XYZ

In estimation of the distance and time of transfer per day like in Table 3, total distance of 400.5 meters was obtained. The longest distance with the most frequency obtained from the packing - export process, inspection packaging process and the bottom-upperbank subcont. As for the process of three experience the intensity of activities four times (4 times) so it is needed an efficiency in the area that allows employees to be able to further speed up the work time due to closer distance.
From Table 3 it also could be seen that the distance of the production process takes a lot of time in a day which amounted to 1673.6 minutes / day. So the alternative calculation process which carried out according to the production flow from the warehouse station to the export station. 
ISSN No:-2456-2165

\begin{tabular}{|c|c|c|c|c|c|c|}
\hline \multirow{2}{*}{$\begin{array}{l}\text { Work } \\
\text { Station }\end{array}$} & \multirow[b]{2}{*}{ From } & \multirow[b]{2}{*}{ To } & \multicolumn{4}{|c|}{ After } \\
\hline & & & $\begin{array}{l}\text { Distance } \\
\text { (Meter) }\end{array}$ & $\begin{array}{c}\text { Process } \\
\text { Turnaround } \\
\text { (Minute) }\end{array}$ & $\begin{array}{c}\text { Transfer } \\
\text { Frequent/Hour }\end{array}$ & $\begin{array}{c}\text { Transfer } \\
\text { Time/Day } \\
\text { (Minute) }\end{array}$ \\
\hline 1 & Warehouse & Cutting & 5,2 & 2,5 & 4 & 80,00 \\
\hline 2 & Cutting & Subcont & 3,4 & 2,2 & 4 & 70,40 \\
\hline 3 & Subcont Upper & Preparation & 4,5 & 3,1 & 4 & 99,20 \\
\hline 4 & Preparation & Sewing & 25,6 & 4,7 & 4 & 150,40 \\
\hline 5 & Sewing & Upperbank & 30 & 5 & 4 & 160 \\
\hline 6 & Subcont Bottom & Upperbank & 5,2 & 2,5 & 4 & 80,00 \\
\hline 7 & Upperbank & Assembling & 24,5 & 4,8 & 4 & 153,60 \\
\hline 8 & Assembling & Inspection & 15,6 & 3,6 & 4 & 115,20 \\
\hline 9 & Inspection & Packing & 16,2 & 3,4 & 4 & 108,80 \\
\hline \multirow[t]{2}{*}{10} & Packing & Exsport & 12,8 & 3,5 & 4 & 112,00 \\
\hline & TOTAL & & 143,00 & & & 1129,60 \\
\hline
\end{tabular}

Table 4:- The estimation over Alternative Layout Between Distance and Transfer Time Per Day on Sample Room at PT XYZ

Based on Table 4 it could be seen that the total distance was 143 meters with the production process taking 1129.6 minutes/day. The change from the longest distance is the packing - export process, inspection - packaging process, and the bottom - upperbank subcont. After the transfer of production process facilities to accelerate and facilitate employees in transfer of production materials.
B. ARC Diagram (Activity Relationship Chart) Method

Distance of movement used as benchmark towards the level of closeness relationship between one facility (department / station) to others. These used method was Activity Relationship Chart (ARC). The level of closeness between facilities by ARC method in this research could be seen as in Figure 3 below.

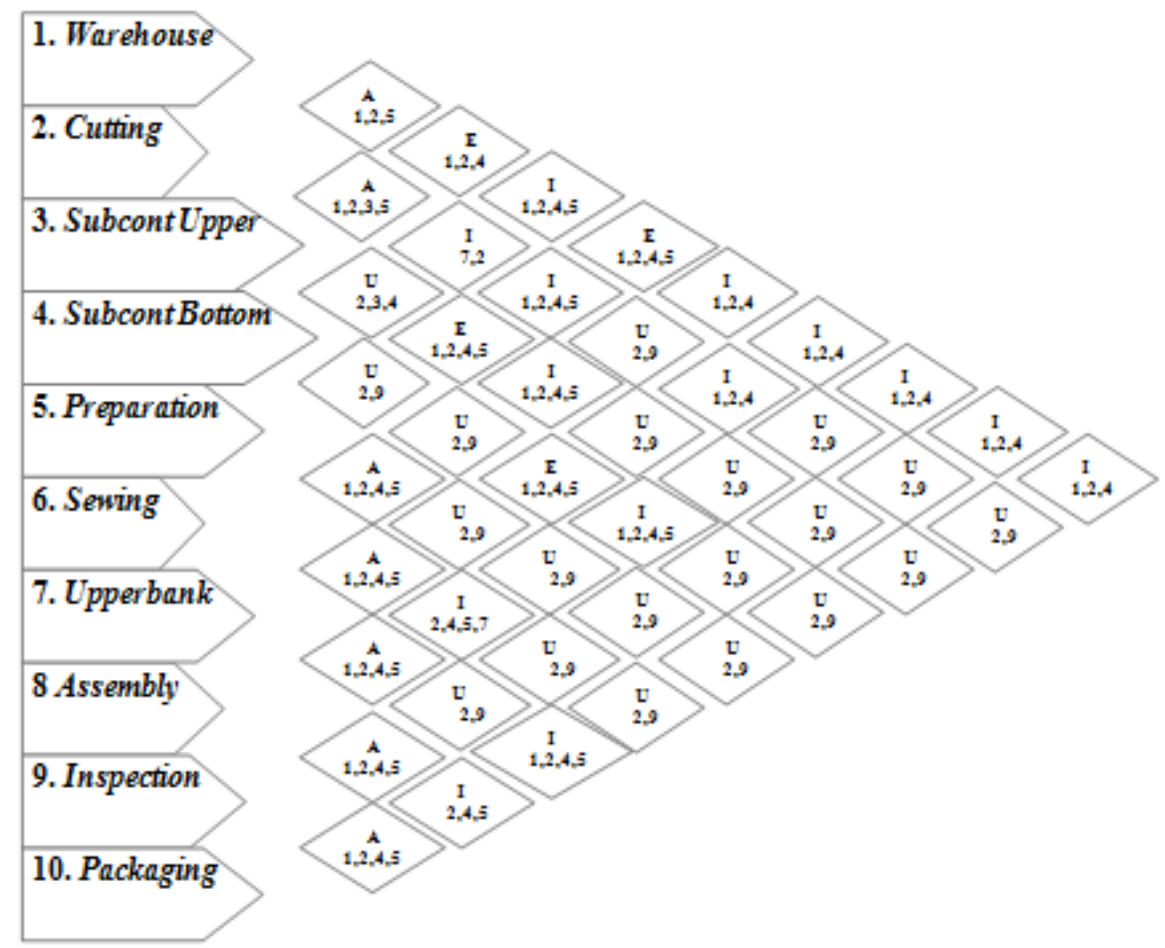

Fig 3:- Activity Relationship Chart (ARC) on Development Sample Room at PT. XYZ 
A connection that has an A value indicates an absolute relationship because it has function and more effective because it close together in the shoe making process. Relationship which have an E value was indicated very important, quite important close relationship because there has process to be carried out but the process passes through one station before the process. Relationships that have a value of I was indicated an important relationship. Relationships that have an $\mathrm{O}$ value indicate a fairly ordinary relationship. But in this chart, there is no $\mathrm{O}$-valued relationship. Relationships that have a $U$ value indicate an insignificant relationship. Relationships that have an $\mathrm{X}$ value was indicate an undesirable relationship, usually this relationship is related to hazardous substances. But again in this chart there is no $\mathrm{X}$-valued relationship.

\section{Efficiency and Productivity Method}

From the layout analysis in the production process, it is necessary to proceed to analyze efficiency in terms of distance, time of transfer and number of workers. From the estimation of efficiency result in terms of distance, time of transfer and number of workers, the total efficiency in terms of distance is $64.29 \%$ and efficiency of transfer time is $32.50 \%$ and with the number of workers from 11 people to 8 people.

\begin{tabular}{|c|c|c|c|c|c|c|c|c|c|c|}
\hline \multirow[b]{2}{*}{$\begin{array}{l}\text { Work } \\
\text { Station }\end{array}$} & \multirow[b]{2}{*}{ From } & \multirow[b]{2}{*}{ To } & \multicolumn{3}{|c|}{ Before } & \multicolumn{2}{|c|}{ After } & \multirow[b]{2}{*}{$\begin{array}{l}\text { Worker } \\
\text { Amount }\end{array}$} & \multicolumn{2}{|c|}{ Improvement } \\
\hline & & & $\begin{array}{l}\text { Distance } \\
\text { (Meter) }\end{array}$ & $\begin{array}{l}\text { Transfer } \\
\text { Time/Day } \\
\text { (Minute) }\end{array}$ & $\begin{array}{l}\text { Worker } \\
\text { Amount }\end{array}$ & $\begin{array}{l}\text { Distance } \\
\text { (Meter) }\end{array}$ & $\begin{array}{l}\text { Transfer } \\
\text { Time/Day } \\
\text { (Minute) }\end{array}$ & & $\begin{array}{c}\text { Eficiency } \\
\text { Layout }\end{array}$ & $\begin{array}{c}\text { Time Transfer } \\
\text { Eficiency }\end{array}$ \\
\hline 1 & Warehouse & Cutting & 12,8 & 144,00 & 1 & 5,2 & 80,00 & 1 & $59,38 \%$ & $44,44 \%$ \\
\hline 2 & Cutting & Subcont & 3,4 & 64,00 & 1 & 3,4 & 70,40 & 1 & $0,00 \%$ & $-10,00 \%$ \\
\hline 3 & Subcont Upper & Preparation & 16,6 & 112,00 & 1 & 4,5 & 99,20 & \multirow{2}{*}{1} & $72,89 \%$ & $11,43 \%$ \\
\hline 4 & Preparation & Sewing & 27,6 & 160,00 & 1 & 25,6 & 150,40 & & $7,25 \%$ & $6,00 \%$ \\
\hline 5 & Sewing & Upperbank & 30 & 160,00 & 1 & 30 & 160 & 1 & $0,00 \%$ & $0,00 \%$ \\
\hline 6 & Subcont Bottom & Upperbank & 43,2 & 208,00 & 1 & 5,2 & 80,00 & 1 & $87,96 \%$ & $61,54 \%$ \\
\hline 7 & Upperbank & Assembling & 24,5 & 153,60 & 1 & 24,5 & 153,60 & 1 & $0,00 \%$ & $0,00 \%$ \\
\hline 8 & Assembling & Inspection & 15,6 & 115,20 & 1 & 15,6 & 115,20 & \multirow{3}{*}{2} & $0,00 \%$ & $0,00 \%$ \\
\hline 9 & Inspection & Packing & 110 & 268,80 & 1 & 16,2 & 108,80 & & $85,27 \%$ & $59,52 \%$ \\
\hline 10 & Packing & Exsport & 116,8 & 288,00 & 2 & 12,8 & 112,00 & & $89,04 \%$ & $61,11 \%$ \\
\hline \multicolumn{3}{|c|}{ TOTAL } & 400,50 & 1673,60 & 11 & 143,00 & 1129,60 & 8 & $64,29 \%$ & $32,50 \%$ \\
\hline
\end{tabular}

\begin{tabular}{ccccc}
\hline Worker Cost Efficiency & Before & After & Gap & Efficiency \\
\hline Worker Almount & 11 & 8 & -3 & \\
\hline Worker Cost Efficency & Rp48.400.000 & Rp35.200.000 & - Rp13.200.000 & $27,27 \%$ \\
\hline
\end{tabular}

\begin{tabular}{|c|c|c|c|c|c|c|c|c|}
\hline \multirow{2}{*}{$\begin{array}{c}\text { Month } \\
\text { July }\end{array}$} & \multicolumn{2}{|c|}{$\begin{array}{c}\text { Target } \\
\text { Cost/Month }\end{array}$} & \multicolumn{2}{|c|}{$\begin{array}{c}\text { Actual } \\
\text { Cost/Month }\end{array}$} & \multicolumn{2}{|c|}{ Efficiency Result } & Total Efficiency & \multirow{2}{*}{$\begin{array}{c}\% \\
5,38 \% \\
\end{array}$} \\
\hline & $\mathrm{Rp}$ & 70.658 .340 & $\mathrm{Rp}$ & 258.497 .399 & $\mathrm{Rp}$ & 13.200 .000 & 245.297.399 & \\
\hline August & $\mathrm{Rp}$ & 70.658 .340 & $\mathrm{Rp}$ & 642.907 .705 & $\mathrm{Rp}$ & 13.200 .000 & 629.707 .705 & $2,10 \%$ \\
\hline September & $\mathrm{Rp}$ & 70.658 .340 & $\mathrm{Rp}$ & 258.497 .399 & $\mathrm{Rp}$ & 13.200 .000 & 245.297 .399 & $5,38 \%$ \\
\hline October & $\mathrm{Rp}$ & 70.658 .340 & $\mathrm{Rp}$ & 258.497 .399 & $\mathrm{Rp}$ & 13.200 .000 & 245.297 .399 & $5,38 \%$ \\
\hline November & Rp & 70.658 .340 & Rp & 153.317 .919 & Rp & 13.200 .000 & 140.117 .919 & $9,42 \%$ \\
\hline December & & 70.658 .340 & Rp & 111.682 .659 & $\mathrm{Rp}$ & 13.200 .000 & 98.482 .659 & $13,40 \%$ \\
\hline Total 2018 & $\mathbf{R p}$ & 423.950 .040 & $\mathbf{R p}$ & .683 .400 .480 & $\mathrm{Rp}$ & 79.200 .000 & Rp 1.604.200.480 & \\
\hline
\end{tabular}

Table 5:- Distance Efficiency Analysis, Transfer Time, Worker Almont and Worker Cost

Based on estimation result, the company could save workers by Rp. 13,200,000 with percentage value of $27.27 \%$ every month. The efficiency value was obtained by calculating the average cost of workers per month of Rp. $4,400,000$ multiplied by the number of workers.
In productivity analysis where the work station process gets more output than before. Based estimation results above it shows that value obtained for six months from productivity results is $100 \%$ whereas the total value of input and output is equal around 51,720 pairs of shoes. 


\begin{tabular}{crrc}
\hline Month & Output Target & Actual Output & Productivity \\
\hline July & 9.680 & 9.680 & $100 \%$ \\
\hline August & 9.240 & 9.240 & $100 \%$ \\
\hline September & 7.600 & 7.600 & $100 \%$ \\
\hline October & 9.200 & 9.200 & $100 \%$ \\
\hline November & 8.400 & 8.400 & $100 \%$ \\
\hline December & 7.600 & 7.600 & $100 \%$ \\
\hline Total 2018 & 51.720 & 51.720 \\
\hline \multicolumn{4}{c}{ Table 6:- Productivity Analysist } \\
\hline
\end{tabular}

\section{Causal Analysis Method (Fishbone)}

Fishbone diagrams could identify various potential causes of an effect or problem and analyze the problem through brainstorming session. To discover which factors can affect the occurrence of productivity targets not achieved in terms of output and cost efficiency then the analysis which carried out using causal diagram or fishbone diagram consisting of several factors:

$>$ The Human Factor (Personnel) consists of age, respect, ignoring work procedures and lack of self-awareness in protecting yourself to use PPE (Personal Protective Equipment).

$>$ Machine / Tool Factors consist of machine life, absence of automatic machines and lack of machines.

- Method Factor consists of not following work procedures, SOPs not being updated and lacking communication.

$>$ Material Factors consist of material delays and supplier work contracts that have expired.

The Sizing Factor (Measurement) still uses manual methods and there has no measurements standards

Factors Noisy work environment.

\section{Fishbone: Not achieving the target output and efficiency cost}

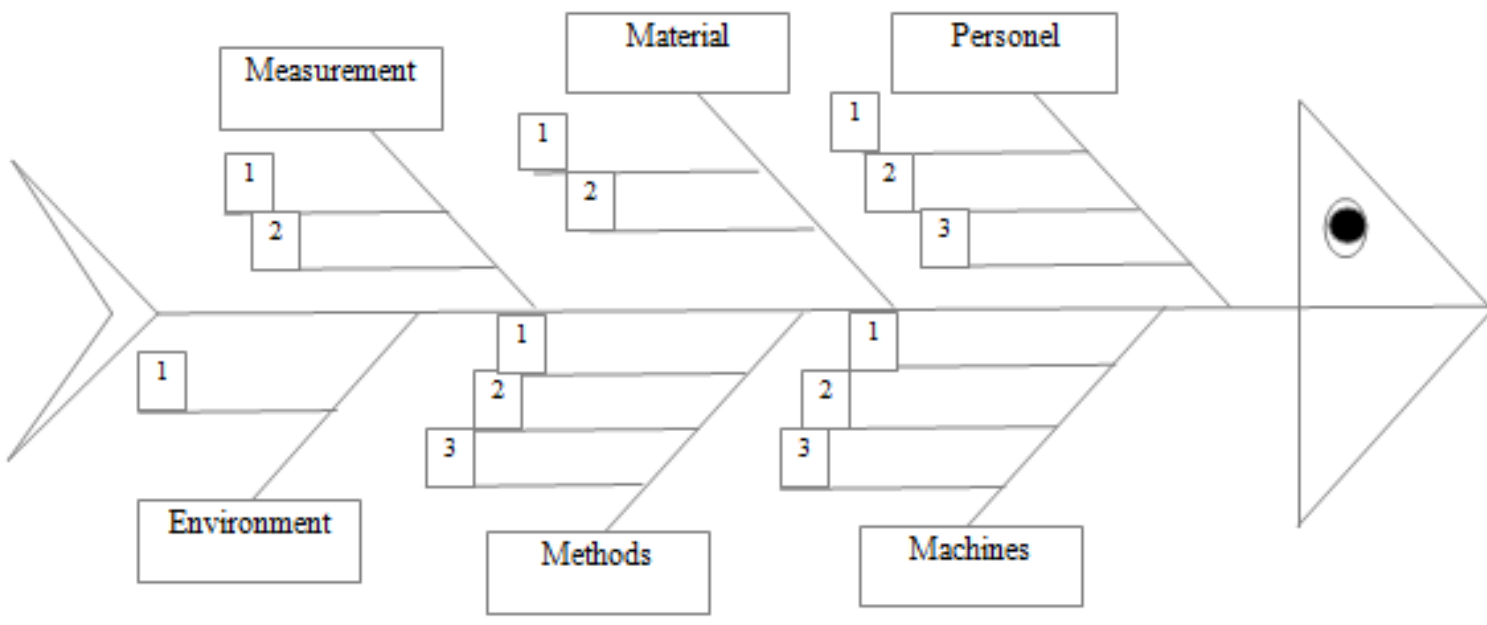

Keterangan :

Personel : 1. Ignoring work procedure

2. Notwearing APD (safety tools)

3. Lacked work motivation/ no rewards

4. Ages

Machine : 1 . Engine life

2. No automatic machine

3. Havenot many production machine

Methods : 1 . Not following work procedure

2. Notupdating SOPs

3. Communication

Materials : 1 . Materials delay

2. Supplier work contact which have expired

Sizing factor : 1. Still usemanual methods and not automatic

2. There is no measurement standard

Environment : 1 . Noisy factor in working environment

Fig 4:- Fishbone diagram on Development Sample Room Mapping Diagram at PT. XYZ 


\section{E. Discussion}

These Research found that the initial and alternative layout analysis tables produce different values. The results obtained from alternative layout analysis table produce work processes from one station to the next station more closely. The total distance in initial layout is 400.50 meters with alternative 143 meters so it has gap value of 257.5 meters and the transfer time per day per minute has decreased from 1673.60 to 1129.60 minute per day so distributing materials even faster and save time processing. In the ARC (Activity Relationship Chart) chart for value A relationships, namely warehouse - cutting - subcontinent upper - preparation - sewing - upperbank - assembling inspection - packaging is absolutely close so the production process becomes faster.

In the efficiency analysis was found that the efficiency of employee costs of $27.27 \%$. This is because there has reduction in number of workers in terms of the process of material transfer from one station to the next, the initial number of workers is 11 to 8 people. The percentage of efficiency results from the average wage cost multiplied by the number of workers there. With the nominal efficiency of Rp. 13,200,000, - every month, the profit for the company in saving the amount is nominal. In productivity analysis, there is no increase in productivity because basically the target or order has been received to be completed in the month. So that the productivity every month is $100 \%$.

In a fishbone chart, where there has causal relationship if efficiency and productivity are not achieved from various factors namely human, machine, method, material, measurement and environmental factors. For human factors or personnel consisting of age, appreciation, ignoring work procedures and lack of introspection in selfprotection to use PPE (Personal Protective Equipment). The engine factor consists of the life of the engine, the absence of an automatic engine and the lack of an engine. The method factor consists of not following work procedures, SOP is not updated and lacking communication. Material factors consist of material delays and supplier work contracts have expired. Material sizing factor still uses manual method and there has no standard of measurement. The last factor is the noisy work environment.

\section{CONCLUSIONS AND SUGGESTIONS}

\section{A. Conclusion}

Based on analysis description results therefore it could be drawn as concluded that:

From the layout analysis result, it was found that reduced distance in the production process, from a total initial distance of 400.5 meters to 143 meters with transfer time per minute decreed from 1673.60 minutes per day to 1129.60 minutes per day so the distributing material faster and will save processing time.

$>$ In the ARC (Activity Relationship Chart) chart for value A relationships, namely warehouse - cutting subcontinent upper - preparation - sewing - upperbank - assembling - inspection - packaging to be called as absolutely close therefore production process becomes faster.

$>$ Cost efficiency of $27.27 \%$ with nominal value of Rp.13,200,000 per month, so there has reduction in actual costs with nominal efficiency. This indirectly as advantage for the company.

$>$ As for productivity analysis, there has no increase in productivity because basically the target or order has been received to be completed that month. So those productivity every month is $100 \%$.

$>$ For fishbone connection, cause and effect, where there has cause-effect relationship so if efficiency and productivity are not achieved from various factors namely human, machine, method, material, sizing and environmental factors. For human factors or personnel consisting of age, appreciation, ignoring work procedures and lack of introspection in self-protection to use PPE (Personal Protective Equipment). The engine factor consists of the life of the engine, there has no automatic engine and the lack of an engine. The method factor consists of not following work procedures, SOP is not updated and communication is lacking. Material factors consist of material delays and supplier work contracts have expired. Material measurement factor still uses manual method and have no standard measurement. The last factor is noisy work environment.

\section{B. Suggestions}

There has several suggestions that could be given as results of these research and advice for further research such as:

$>$ Providing regular training for each employee to get to know about personal safety and create a sense of ownership of the company to be more productive and effective at work.

$>$ Continually improvement to increase the company's targets so the company would gained lots of profit.

$>$ This research was conducted with lots of limitations so for the next researcher is expected to study and learn more sources and related references therefore the results can be better and more complete.

\section{REFERENCES}

[1]. Asfihan.(2009). PengertianEfisiensi.https://ruangpeng etahuan.co.id/pengertian-efisiensi/. (Diakses tanggal 20 Februari 2020)

[2]. Gaspersz, V. (2000). Manajemen Produktivitas Total (Strategi Peningkatan Produktivitas Bisnis Global). Jakarta: PT. Gramedia Pustaka Umum.

[3]. Hansen, Don R dan Maryanne M. Mowen. (2009). Managerial Accounting: Akuntansi Manajerial, edisi 8. Dialih Bahasakan Oleh Deny Arnos Kwary. Jakarta: Penerbit Salemba Empat.

[4]. Hasibuan, Malayu S.P. (1984). Manajemen dasar, pengertian dan masalah. Jakarta: Penerbit Gunung Agung.

[5]. Heizer, J., dan Render, B. (2011). Manjemen Operasi. Edisi Kesembilan. Salemba Empat, Jakarta. 
[6]. Mulyadi. (2009). Akuntansi Biaya, Edisi ke 5. Yogyakarta: STIE YKPN.

[7]. Mulyamah. (1987). Manajemen Perubahan. Jakarta: Yudhistira.

[8]. Prima, Fithri dan Regina Yulinda Sari. (2015). "Analisis Pengukuran Produktivitas Perusahaan ALSINTAN CV.CHERRY SARANA AGRO". Jurnal Optimasi Sistem Industri, Vol. 14 No. 1, April 2015: 138-155.

[9]. Purba, H.H. (2008). Diagram fishbone dari Ishikawa. (http://hardipurba.com/2008/09/25/diagram-fishbonedari-ishikawa.html). Diakses tanggal 18 April 2019 (21.19 WIB).

[10]. Purnomo, Hari. 2004. Pengantar Teknik Industri. Yogyakarta : Graha Ilmu.

[11]. Sumanth, D.J. (1984). Productivity Engineering and Management. New York: Mc Graw-hill Book Company.

[12]. Tague, N. R. (2005). The quality toolbox. (2th ed.). Milwaukee, Wisconsin: ASQ Quality Press. Available from http://asq.org/qualitypress/display-item/index.html?item $=$ H1224. Diakses tanggal 18 April 2019 (21.20 WIB).

[13]. Timpe, A. D. (1984). Kinerja (Performance). Jakarta: PT.Elex Media Komputindo.

[14]. Wignjosoebroto, S. (2009). Tata Letak Pabrik dan Pemindahan Bahan. Edisi Ketiga. Guna Widya, Surabaya. 